\title{
THE PEREGRINE FALCON Falco peregrinus (Tunstall, 1771) IN SERBIA
}

\author{
Bratislav Grubač \\ Nemanjina I/14, 35250 Paraćin, Serbia, grubacbratislav@gmail.com
}

\begin{abstract}
This paper presents an overview of summarized data on the distribution, population, trend, ecology (habitat, feeding and breeding) and threats to the peregrine falcon Falco peregrinus (Tunstall, 1771) in Serbia, with special reference to the recent period. Peregrine falcon is in general widely distributed sedentary bird, the habitat of which ranges from lowlands to high-mountainous areas at the approximate altitudes of 85 to $2500 \mathrm{~m}$. Current, rather reduced breeding population from the period between 2014 and 2018, mostly occurs in the eastern, and much less in the southeastern, western, central and southern parts of the country. According to data for the period 1977-1997, one rather small population was breeding in the mountainous regions of Kosovo and Metohija. There is no reliable evidence of this species breeding in Vojvodina. In the distant past, the period from late $19^{\text {th }}$ century to the 1970s, this species was very rare in Serbia. In the period 1977-1997, as well at the beginning of $21^{\text {st }}$ century, the population increased from approximately 40-60 to 65-90 pairs. The current population exhibited a marked decline with the estimated 30-50 breeding pairs in the period 2014-2018. The peregrine falcon mostly breeds on the cliffs in rocky and hilly-mountainous areas up to $1.700 \mathrm{~m}$ of altitude. It mainly feeds on pigeons and doves, mostly Columba liviaf. domestica, $C$. livia, C. palumbus, Streptopelia turtur and S. decaocto, as well as thrushes Turdus spp., common starlings Sturnus vulgaris, crows and many other birds. Peregrine falcon usually lays eggs from the second half of March to early April, while the young start leaving the nest from late May to mid-June. Breeding success is on average 2.3 young (varies between 1 and 4) per successful nesting $(\mathrm{N}=53)$, whereas productivity is 1.9 young per pair $(\mathrm{N}$ $=64$ ). Illegal killing of the peregrine falcons by pigeon breeders and hunters represents a major threat and a cause of $94 \%$ mortality of the species, thus being a major problem of this species' conservation in Serbia.
\end{abstract}

Key words: Peregrine falcon Falco peregrinus, Serbia, distribution, population, trend, ecology, threats.
Извод: У раду је дат сажет преглед података о дистрибуцији, популацији, тренду, екологији (станиште, исхрана и гнежђење) и угрожавајућим факторима сивог сокола Falco peregrinus (Tunstall, 1771) у Србији, са посебним освртом на савремени период. Врста је широко распрострањена станарица која се среће од низија до високопланинских области, оквирно од 85 до 2500 m н.в. Савремена, редукована, гнездећа популација, која се односи на период од 2014. до 2018. године, углавном се среће у источним, а знатно мање у југоисточним, западним, централним и јужним деловима земље. Према подацима за период 1977-1997. године, мања популација се гнезди у планинским регионима Косова и Метохије. Нема поузданих доказа о гнежђењу врсте на подручју Војводине. У прошлости, у периоду од краја 19. века до око 1970их, врста је била веома ретка у Србији. У периоду 1977-1997. године, као и почетком 21. века, популација се повећала са 40-60 на 65-90 парова. Савремена популација показује упадљиво опадање, и процењена је на 30-50 гнездећих парова за период 2014-2018. године. Сиви соко се, углавном, гнезди на литицама у стеновитим брдско-планинским областима до 1.700 m н.в. Главна храна су му голубови и грлице, углавном Columba livia f. domestica, као и C. livia, C. palumbus, Streptopelia turtur и S. decaocto, и такође дроздови Turdus spp., чворци Sturnus vulgaris, вране и многе друге птице. Јаја углавном полаже од друге половине марта до почетка априла, док младунци полећу крајем маја до средине јуна. Успешност гнежђења је 2,3 младунца или 1-4 младунца по успешном гнежђењу $(\mathrm{N}=$ 53), и продуктивност је 1,9 младунаца по пару ( $\mathrm{N}$ = 64). Илегално убијање сивих соколова од стране одгајивача голубова, као и ловаца, велика је опасност и узрок око $94 \%$ морталитета врсте, као и главни проблем њеног очувања у Србији.

Кључне речи: Сиви соко Falco peregrinus, Србија, распрострањеност, популација, тренд, екологија, угрожавајући фактори. 


\section{INTRODUCTION}

The peregrine falcon Falco peregrinus (Tunstall, 1771) was a rare and insufficiently studied species in Serbia in the past. Only a few data on this species can be found in ornithological reports and articles dating back to the end of the $19^{\text {th }}$ century and further until 1970s (Dombrovski, 1891, 1895; Rajzer, 1904; Reiser, 1939; Matvejev, 1950, 1964; Marčetić, 1956, 1971; Marčetić \& Andrejević, 1960; Antal et al., 1969). This data show that the peregrine falcon was a very rare sedentary and nesting bird mostly occurring in mountainous areas of Serbia. First detailed research on the status and ecology of this species in Serbia were initiated in 1980 within projects on research and conservation of birds of prey and bird fauna in general (Vasić, 1980; Vasić \& Grubač 1983; Vasić et al., 1985; Grubač, 1986; Marinković \& Grubač, 2000; Grubač \& Puzović, 2003; Grubač et al., 2013, 2018). The population began to increase significantly at the end of the $20^{\text {th }}$ and the beginning of the $21^{\text {st }}$ century (Marinković \& Grubač, 2000; Puzović et al. 2009), however it experienced a sharp decline in the recent period (Puzović et al., 2015).

Bearing in mind the insufficient research and vulnerability of the peregrine falcon in Serbia, the author presents an overview of the distribution, population and trend, ecology (habitats, feeding and some aspects of breeding), threats and problems of protecting this species, which is based on bibliographic and field research, with particular reference to the contemporary period.

\section{MATERIALS AND METHODS}

The basic material for this paper consists of the summarized bibliographic and author's non-published data collected during field research in the period 1980-2018. In addition, numerous non-published data gathered by other ornithologists, as well as associates in the field, were used in this paper. Special emphasis was on the results of recent research on the species state, which were obtained during the project activities: "Survey, monitoring and conservation of peregrine falcon in Serbia", within the program of activities of the Institute for Nature Conservation of Serbia in the period 2014-2018.

Standard ornithological methods (mostly modified transect and observation from various points) were used during the collection of data on the peregrine falcon, which were adapted to this species. In addition, the survey and monitoring of the species was conducted on its well-known and potential breeding sites. The questionnaire for bird watchers, falconers and pigeon keepers was used as an auxiliary or additional method for identifying and collecting data on the threatening factors (especially considering the issue of killing individuals and the mortality of species etc.), as well as for discovering the presence of the species on some previously unknown sites. These data have been critically analyzed and checked.

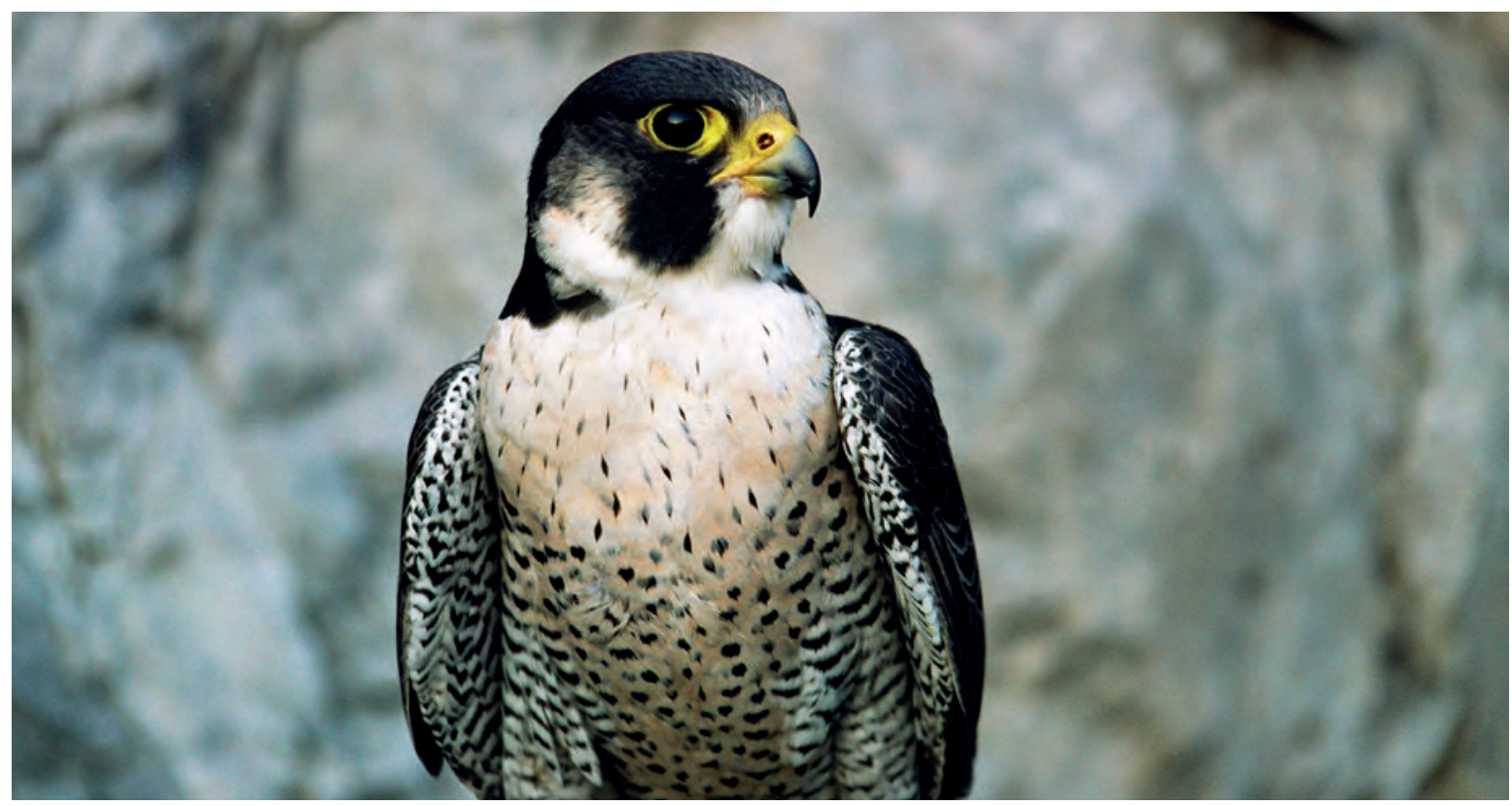

Fig. 0: Adult male of the peregrine falcon. Western Serbia, December 2003. Photo: B. Grubač 


\section{RESULTS AND DISCUSSION}

\section{Distribution, population and trends}

The peregrinefalcon is widely distributed sedentary bird, the habitat of which ranges from lowlands to high-mountainous areas at the approximate altitudes of 85 to $2500 \mathrm{~m}$. Breeding distribution includes mostly rocky and hilly-mountainous areas of the eastern, south-eastern, central, western and southwestern Serbia, as well as the territory of Kosovo and Metohija in the contemporary period (1980-2018). Furthermore, the presence of species in the breeding period implies a possible sporadic breeding in Vojvodina, which has not been confirmed even though there are indications (Marčetić, 1956; Obradović, 1997; Stojnić, 2001; Stojnić \& Puzović, 2008; Sćiban et al., 2015). Contemporary breeding distribution of the peregrine falcon in Serbia according to the research conducted in the period between 2014 and 2018 has significantly been reduced due to killings. The species population in eastern Serbia remained relatively well-preserved, while in other areas it was mostly reduced.

The peregrine falcon was a very rare species in Serbia in the period from the second half of the $19^{\text {th }}$ century to the second half of the $20^{\text {th }}$ century (Matvejev, 1950, 1963; Vasić et al., 1985; Grubač, 1986). According to initial estimates by Marinković \& Grubač (2000) the species numbers in the period from 1977 to 1979 was about 40 to 60 pairs, and between 1994 and 1996 it was estimated at 62 to 81 pairs. According to estimates, the species trend exhibited a slight increase. Based on the estimates by Puzović et al. (2003) in the period between 1995 and 2002 , the population was between 65 and 80 breeding pairs, and the species trend was assessed as stable. The largest population was estimated at 75-90 pairs at the beginning of the $21^{\text {st }}$ century (Puzović et al., 2009). However, later estimates for the period 20112013 showed 51-63 breeding pairs, while the shortterm trend for the period 2000-2013 was assessed as slightly or moderately declining (Puzović et al. 2015). The total breeding population of the peregrine falcon in Serbia was estimated at about 170 breeding pairs for the period between the second half of the $20^{\text {th }}$ century to date. The estimates were done on the basis of all known, determined, probable and possible breeding territories or known nesting sites, which were provided in all so far published papers, as well as according to non-published data. According to the latest research conducted in the period between 2014 and 2018, the population was estimated at about 30-50 breeding pairs. The absence of pairs and the presence of only individuals at several well-known breeding territories were determined, which indicated significant changes and population decline. The long-term trend for the period 1998-2018 was estimated as a marked decline, which was as a result of continuous and intense killing by pigeon breeders. However, the research showed no new data on the state of population on the entire territory of Serbia. The current state of the population in Kosovo and Metohija is unknown and estimates are mainly given on the basis of the research conducted in the period from 1980 to 1997. A rather small population of this species in the mentioned period was estimated at about 10-15 pairs, and its trend was probably stable and remained stable.

\section{Ecology - habitat, feeding and breeding}

Habitat: In Serbia, the peregrine falcon breeds on cliffs in rocky and hilly-mountainous areas at the approximate altitudes of $200 \mathrm{~m}$ to $1700 \mathrm{~m}$ (Grubač, 1986; Marinković \& Grubač 2000; Grubač \& Puzović, 2003; Grubač et al. 2013, 2018). Even though it has not been confirmed, according to the questionnaires filled in by falconers, pigeon keepers and bird watchers, as well as according to some literature data (Marčetić, 1956; Marinković \& Grubač, 2000), it is quite possible that this species breeds in lowland areas, on tall buildings and in the trees of both inhabited and uninhabited areas. In search of prey, this species occurs in various types of habitats, mainly in hilly and mountainous areas on rocks and cliffs, rocky grounds, pastures and forest habitats (at the altitudes of approximately 200 to $2500 \mathrm{~m}$ ), as well as in human settlements and cities, around aquatic and other habitats in lowlands.

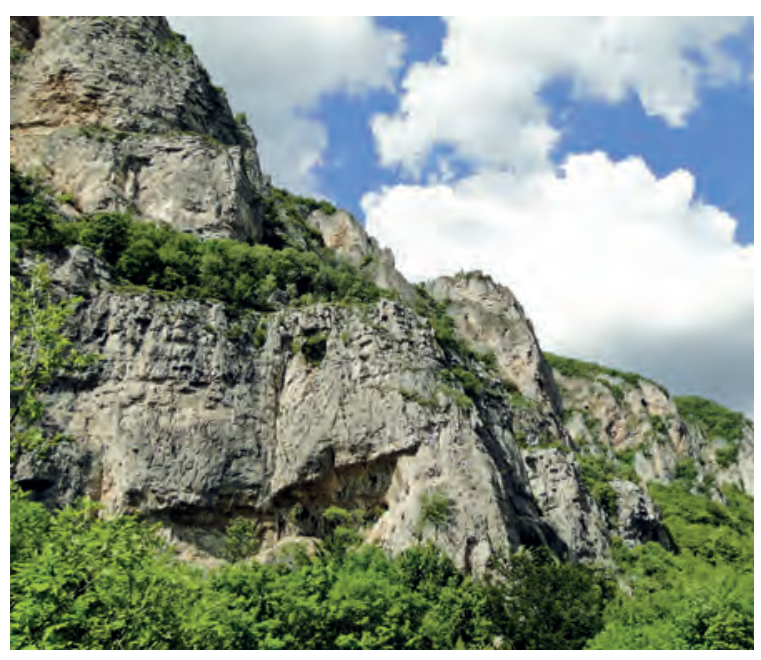

Fig. 1: Mountainous limestone cliffs - typical breeding site and habitat of the peregrine falcon in Serbia, Eastern Serbia, May $7^{\text {th }}, 2016$. Photo: B. Grubač 
Feeding: The main prey of the peregrine falcon in Serbia consists of various birds from the pigeon family, usually Columba livia $f$. domestica, but also Columba livia and C. palumbus, from the doves family, Streptopelia turtur and $S$. decaocto, and to a lesser degree from the family of true thrushes Turdus spp., common starlings Sturnus vulgaris, various crows (Eurasian jay Garrulus glandarius, jackdaw Corvus monedula, common magpie Pica pica) and many other bird species (Dombrovski, 1895; Grubač, 1986; Pelle, 1990; Žiljak, 1995).

Breeding density: Average breeding density of the peregrine falcon population in Serbia in the period 1994-96 was 0.072 breeding pairs per $100 \mathrm{~km}^{2}$, while the largest density was in Kosovo and Metohija and southwestern Serbia with 0.205 and 0.175 breeding pairs per $100 \mathrm{~km}^{2}$ (Marinković \& Grubač, 2000). The largest breeding density of the peregrine falcon was recorded in the area of the National Park Đerdap in eastern Serbia during research conducted in the period from 2010 to 2011, where eight breeding pairs were recorded at approximately $640 \mathrm{~km}^{2}$, that is 10 breeding pairs at approximately $1500 \mathrm{~km}^{2}$ (Grubač et al., 2013). According to the calculation, in the surroundings of the National Park Đerdap, there was one breeding pair at $80 \mathrm{~km}^{2}$, whereas in the wider area one pair was breeding at $150 \mathrm{~km}^{2}$. Only 7-8 breeding pairs at an area of $1000 \mathrm{~km}^{2}$ were recorded on the mountain massif of Prokletije (Kosovo and Metohija) during research conducted in the period from 1994 to 1997 (Grubač \& Puzović, 2003). The calculated breeding density was one pair at approximately $125-142 \mathrm{~km}^{2}$. Average breeding density of the total peregrine falcon population in Serbia was estimated at 0.19 breeding pairs at $100 \mathrm{~km}^{2}$. Average breeding density of the present population in Serbia was estimated at 0.03 0.05 breeding pairs at $100 \mathrm{~km}^{2}$.

Breeding season: According to numerous observations and calculations, the peregrine falcon in Serbia mostly lays eggs in the second part of March or in the beginning of April, and the young leave their nest in the period from the end of May to mid-June, while in rare cases this lasts till the second half of July, probably in case of repeated attempts or late broods (Grubač, 1986).

Breeding success The peregrine falcon in Serbia has on average 2.3 (varies in range $\mathrm{R}=1-4$ ) young per successful breeding ( $\mathrm{N}=53$ successful breedings in the period from 1980 to 2018). Productivity was 1.9 young per pair $(\mathrm{N}=64$ in the period from 1980 to 2018).

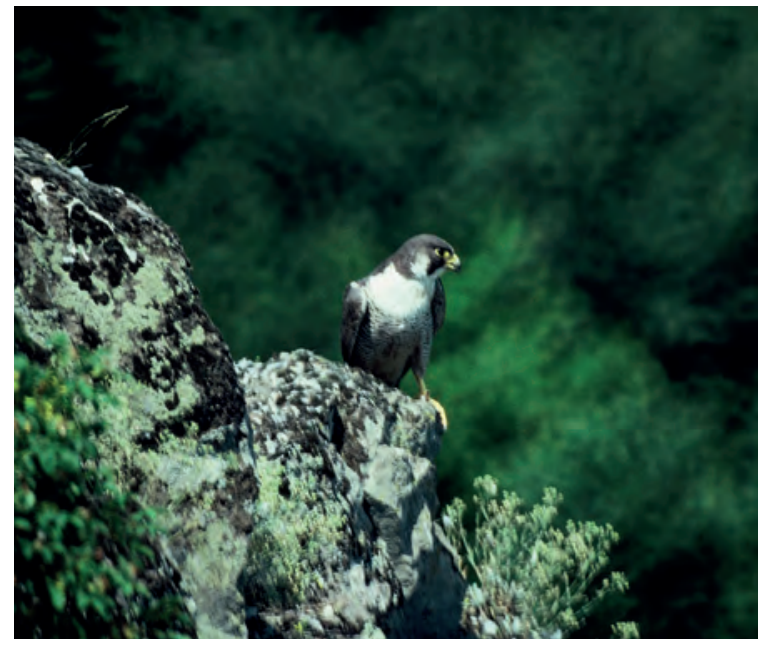

Fig. 2: An adult female of the peregrine falcon near the nest, southern part of Central Serbia, July 2 ${ }^{\text {nd }}, 1982$. Photo: B. Grubac

\section{Threats and conservation problems}

The main threats and conservation issues related to the peregrine falcon in Serbia are killing (various methods of intended killing by firearms, three-way hooks and different traps in order to kill, poison, as well as to kill young in their nests etc.), nest robbing, birds colliding with power lines, wires and different objects, loss and degradation of habitats, disturbance, probably contamination (due to uncontrolled use of pesticides and other toxic and dangerous chemicals) and electrocution.

The killing of the peregrine falcons by pigeon keepers and hunters was very common in Serbia in the past (Rašković, 1905; Dombrovski, 1895; Kuhn, 1898; Marčetić, 1956, 1971; Marčetić \& Andrejević, 1960; Garovnikov, 1988; Vasić \& Obratil, 1990; Marinković \& Grubač, 2000). The recent illegal killings of the peregrine falcons and other birds of prey (the saker falcon, northern goshawk, Eurasian sparrowhawk etc.) by pigeon keepers in Serbia have reached alarming proportions and led to the large decline of population numbers of these species, pushing some of them to the brink of extinction.

According to research, at least 163-166 peregrine falcons were killed in Serbia by pigeon keepers in the period 1960-2018, while 22 individuals were killed by hunters. There is also unofficial data on the killing of 10-11 young in their nests by pigeon keepers. Compared to the total number, at least 160 individuals were killed only between 1991 and 2018. The total number of killed birds is probably significantly higher because a large number of killed birds have not been recorded. With its approximately $94 \%$ death rate, 
illegal killing is the most common cause of death of peregrine falcons in Serbia.

Major threat to the peregrine falcon and other birds of prey, and indirectly to other animal species, is the intentional use of poisons and three-way hooks. A specific problem is the detection of these illegal activities in the field, and in particular the perpetrators, because these activities are done very discreetly. The use of poisons implies the lubrication of live pigeons' feathers with poisons or other toxic chemicals (e.g. creosane, carbofuran/furadan). Figure 3 shows a dead immature peregrine falcon that was confirmed to had been poisoned by furadan. The poisoned bird was found in Novi Sad on June 24 $4^{\text {th }}, 2017$ (N. Stojnić, pers. com.). In addition, the placement of three-way hooks on domesticated pigeons by pigeon keepers is one of the common methods used to kill peregrine falcons and other species of birds of prey (Figure 4).

According to the mentioned questionnaires, nest robbing, that is, stealing young birds or eggs of the peregrine falcon for the purpose of falconry and private collections by foreign and domestic robbers has been a relatively common phenomenon since 1970s. The proportions of current illegal nest robbing and trade in the peregrine falcon in Serbia are unknown, and yet certain number of such cases is evident. This is also associated with illegal killing and capturing by pigeon keepers, since a number of captured live, injured and dead birds are being sold by pigeon keepers for various purposes (falconry, holding in captivity, as well as for private taxidermy collections).

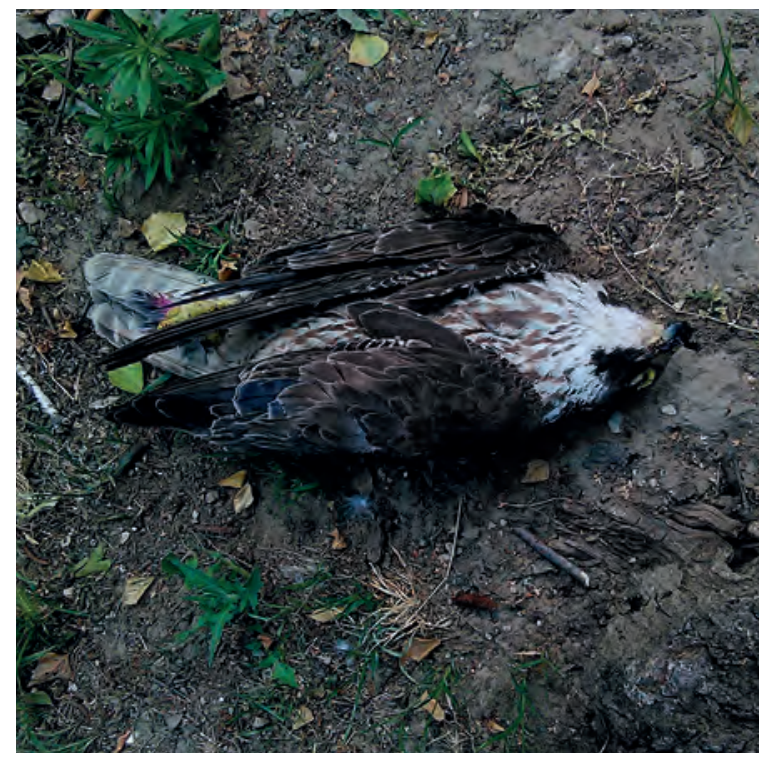

Fig. 3: A dead immature peregrine falcon poisoned by pigeon keepers using furadan, Novi Sad, June $2^{\text {nd }}$, 2017. Photo: N. Stojnić
Death or injuries to peregrine falcons due to collisions with various wires and objects are less common. Five such cases were recorded in Serbia. Marčetić \& Andrejević (1960) state one case of a female that suffered serious injuries, which were caused by colliding with a barbed wire while chasing prey near Lepinje on June $15^{\text {th }}, 1959$. Pigeon keeper Z. Stanić found a seriously injured adult peregrine falcon which had collided with a building while hunting down a domesticated pigeon in Užice in August 1996. B. Šojić reported one seriously injured female found after it had probably collided with an electric line near the village of Zablaće in the surroundings of Čačak on January $3^{\text {rd }}, 2001$. Three days after that the bird died. V. Pajević claimed that one male was killed while chasing prey and colliding with a window glass of a hospital in Kragujevac in February 2004. According to the questionnaire, one immature female with a broken wing was found in Čačak in December 2009. It is assumed that the bird probably collided with some object.

The loss and degradation of habitats and disturbance of the peregrine falcon at their breeding sites in Serbia also represent threats, although no detailed research has been conducted on the proportions and consequences of their effects. Most likely there are cases of contamination of peregrine falcons in food chains, due to excessive use of pesticides and other chemicals in agricultural production and other activities, as well as cases of electrocution, however there is no data to confirm that.

Considering the fact that peregrine falcon is endangered species in Serbia, it is necessary to take urgent measures and activities on species protection

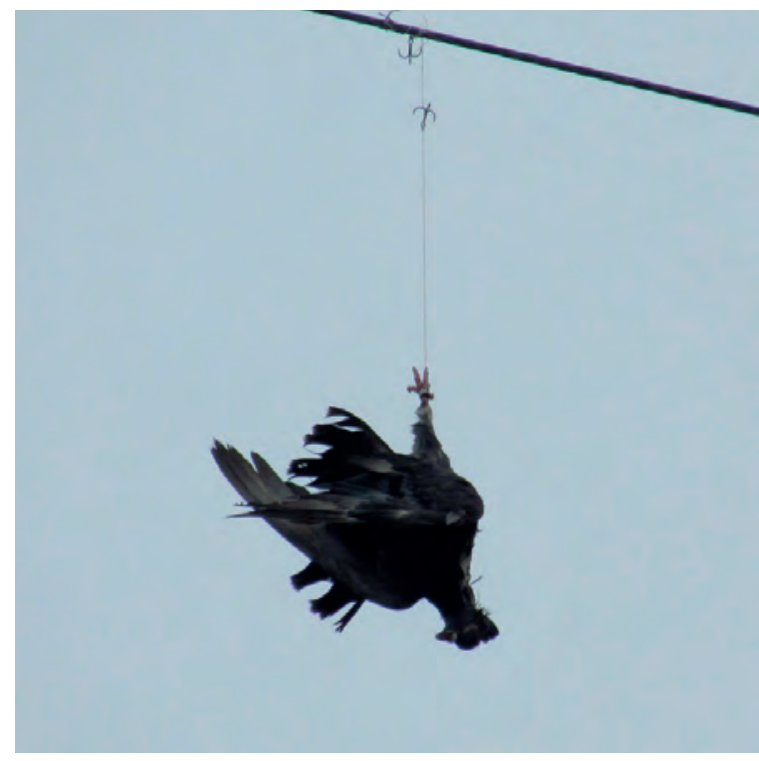

Fig. 4: A dead feral pigeon attached to an electric line with three-way hook, surroundings of the village Svojnovo near Paraćin (Serbia), January $24^{\text {th }}$, 2013. Photo: B. Grubač 
(Grubač et al., 2018). These would involve the urgent prevention and suppression of poisoning and other methods of killing birds by pigeon keepers and hunters, as well as of nest robbing and disturbing birds in their nests. In addition, a detailed and organized research and monitoring of the state of population and the trend of species, as well as of threatening factors is necessary. If further decline in the population numbers was determined, it would be necessary to establish a center for artificial reproduction in captivity, where injured individuals not capable of independent life in the wild would be used for such a purpose.

\section{ACKNOWLEDGMENTS}

I would like to express my gratitude to the following colleagues for the data provided: Slobodan Puzović (Novi Sad), Bogdan Šojić (Čačak), Slobodan Kulić (Leskovac), Brano Rudić (Užička Požega), Milan Glavonjić (Nova Varoš), Milorad Pašić (Zaječar), Nikola Stojnić (Novi Sad), Draženko Rajković (Novi Sad), Miloš Radaković (Belgrade), Ivan Medenica (Pirot), Dimitrije Radišić (Novi Sad), Tibor Buza (Senta), Ivica Rajović (Jagodina), Dragan Trajković (Kraljevo), Dragan Đekić (Valjevo), Ognjen Krnetić (Valjevo), Predrag Marković (Valjevo), Radoslav Novčić (Kriva Reka near Brus), Miroslav Stevanović (Niš), Zoran Stojković (Niš), Igor Aleksić (Vranje), Mihajlo Stanković (Sremska Mitrovica), Vojkan Petrović (Svrljig), Velja Pajević (Kragujevac), Nenad Dučić (Prijepolje), Vladimir Stevanović (Belgrade), Javor Rašajski (Vršac), Ivan Đurašković (Niš), Vladan Vučković (Beograd), Gordan Pomorišac (Belgrade), Aleksandar Pantelić (Belgrade), Hani Girgis (Krnjača near Belgrade). Also, the author would like to thank Nikola Radenković and Bojana Bojović (Belgrade) for translating the text into English.

\section{REFERENCES}

Antal, L., Fernbach, E., Mikuška, J., Pelle, I. \& Szlivka, L. 1969. Register of Birds of the autonomous Province of Vojvodina. Larus 23: 73-127.

Dombrowski, E. 1891. Gassamelte ornithologishe Beobachtungen aus dem Jahre 1890. Mitt. $d$. ornith. Vereins, Wien.

Dombrovski, E. 1895. Osnovi ornitologije sjeverozapadne Srbije. Glasnik Zemaljskog muzeja u Bosni i Hercegovini 7: 63-104.

Garovnikov, B. 1988. Katalog zbirke ptica u Pokarjinskom zavodu za zaštitu prirode u Novom Sadu. - Priroda Vojvodine 3: 1-88, Novi Sad.

Grubač, B. R. 1986. Beleške o gnežđenju i ponašanju sivog sokola (Falco peregrinus Tunstall, 1771) u jugoistočnoj Jugoslaviji. - Larus 36-7: 189-203.
Grubač, B., Milovanović, Z. \& Šekler, M. 2013. Ptice Đerdapa/Birds of Djerdap. - JP Nacionalni park "Đerdap" - Zavod za zaštitu prirode Srbije Veterinarski specijalistički institut "Kraljevo", Donji Milanovac - Beograd. (in Serbian and English)

Grubač, B., Pantović, U. \& Ružić, M. 2018. Falco peregrinus. In: Radišić, D., Vasić, V., Puzović, S., Ružić, M., Šćiban, M., Grubač, B., Vujić, A. eds. Crvena knjiga faune Srbije III - Ptice. Beograd: Zavod za zaštitu prirode Srbije, Univerzitet $\mathrm{u}$ Novom Sadu, Prirodno-matematički fakultet, Departman za biologiju i ekologiju i Društvo za zaštitu i proučavanje ptica Srbije. pp 285-288.

Grubač, B. \& Puzović, S. 2003. Fauna ptica. Metohijske Prokletije - prirodna i kulturna baština. Zavod za zaštitu prirode Srbije. Beograd, pp. 279-299.

Hill, D. 1985. Some contributions to the avifauna of southern parts of Serbia. Glasnik prirodnjačkog muzeja u Beogradu B 40: 191-206.

Kuhn, L. 1898. A Ragadozo Madarak Torontal Varmegy Madarvila-Gaban (Ptice grabljivice Torontalske županije). Sent Ištvan, Budimpešta. (Translation on Serbian: Valerija Macković \& Marija Petrov, Narodni muzej Zrenjanin).

Kulić, S. 2005. Sivi soko Falco peregrinus lovi slepe miševe. Ciconia 14: 116-117.

Mandić, R. \& Puzović, S. 1988. Prilog za faunu ptica Stare planine. Zbornik radova - Prvih deset godina BID „Josif Pančić“, Beograd, str. 107-124.

Marčetić, M. 1956. Peregrine (Falco peregrinus) in the Teritory of Vojvodina and its breeding on buildings. Larus 9-10: 139-142.

Marčetić, M. 1971. Ptice grabljivice. Dnevnik, Novi Sad. Marčetić, M. \& Andrejević, D. 1960. Ornitofauna Kosova i Metohija. Rilindja, Priština.

Marinković, S. \& Grubač, B. 2000. Sivi soko/ Peregrine Falcon Falco peregrinus. In: Puzović, S. (ed.) Atlas ptica grablivica Srbije/Atlas of Birds of Prey of Serbia, Zavod za zaštitu prirode Srbije, Beograd/ Belgrade, pp. 177-182. (in Serbian and Englsh summary).

Matvejev, S. D. 1950. Rasprostranjenje i život ptica u Srbiji (Ornithogeographia Serbica). SANU, monografija, 161, Beograd (in Serbian).

Matvejev, S. D. 1963. Višegodišnje i sezonske promene brojnosti ptica grabljivica u Srbiji. - Arhiv bioloških nauka 15: 127-147, Београд.

Obradović, R. 1997. Sivi soko (Falco peregrinus) posmatran u doba gnežđenja. - Ciconia 6: 113.

Obradović, R. 1997. Sivi soko (Falco peregrinus) posmatran u doba gnežđenja. Ciconia 6: 113. 
Пантовић, У. 2015. Прелиминарна инвентаризација европски значајних врста птица у клисурама Србије. Заштита природе 65/1: 21-32, Београд.

Pelle, I. 1990. Sivi soko Falco peregrinus u Zrenjaninu. - Ciconia 2: 95-96.

Puzović, S., Radišić, D., Ružić, M., Rajković, D., Radaković, M., Pantović, U., Janković, M., Stojnić, N., Śćiban, M., Tucakov, M., Gergelj, J., Sekulić, G., Agošton, A. \& Raković, M. 2015. Ptice Srbije: procena veličina populacija $i$ trendova gnezdarica 2008-2013. Društvo za zaštitu i proučavanje ptica Srbije - Prirodno-matematički fakultet, Departman za biologiju i ekologiju, Univerzitet u Novom Sadu, Novi Sad.

Puzović, S., Sekulić, G., Stojnić, N., Grubač, B. \& Tucakov, M. 2009. Značajna područja za ptice u Srbiji. - Ministarstvo životne sredine i prostornog planiranja, Zavod za zaštitu životne sredine Srbije, Pokrajinski sekretarijat za zaštitu životne sredine i održivi razvoj.

Puzović, S., Simić, D., Saveljić, D., Gergelj, J., Tucakov, M., Stojnić, N., Hullo, I., Ham, I., Vizi, O., Šćiban, M., Ružić, M. Vučanović, M. \& Jovanović, T. 2003. Ptice Srbije i Crne Gore - veličine gnezdilišnih populacija i trendovi: 1990-2002. [Birds of Serbia and Montenegro - sizes of breeding populations and trends: 1990-2002.] Ciconia 12: 35-120, Novi Sad (in Serbian and English summary).

Rajzer, O. 1904. Izvještaj o uspjehu ornitoloških putovanja u Srbiji 1899. i 1900. Glasnik Zemaljskog muzeja u Bosni i Herzegovini 16: 125-152.

Rašković, M. N. 1906. O tičijem svetu u Krajini. I kongres srpskih lekara i prirodnjaka, Beograd, pp. 1-16. (in Serbian)

Reiser, O. 1939. Materialien zu einer Ornis Balcanica. I Bosnien und Hercegovina nebst teilen von Serbien und Dalmatien. - Selbstverlag des Museums, Wien.
Ružić, M. \& MacCurrach, R. 2005. Peregrine Falcon Falco peregrinus. Acrocephalus 26 (125): 114.

Sekulić, V., Perić, V., Paković, Z., Puzović, S. \& Milenković, V. 1986. Prilog za ornitofaunu Zlotske klisure i njene okoline. Istraživač 1: 227-231, Beograd.

Stojnić, N. 2001. Ornitofauna površinskih kopova Fruške gore. - Ciconia 10: 93-107.

Stojnić, N. \& Puzović, S. 2008. Indicije gnežđenja sivog sokola Falco peregrinus na Fruškoj gori. Ciconia 17: 89.

Šćiban, M., Rajković, D., Radišić, D., Vasić, V. \& Pantović, U. 2015. Ptice Srbije - kritički spisak vrsta. - Pokrajinski zavod za zaštitu prirode Srbije i Društvo za zaštitu i proučvanje ptica Srbije, Novi Sad.

Škorpíková, V. 2010. Šta povezuje crvenotrbu crvenrepku, Šar planinu i češku ornitologiju ? Ciconia 19: 9-11.

Vasić, V. F. 1980. Prilozi za faunu ptica južnih delova SR Srbije (prvi deo). Zbornik radova o fauni Srbije 1: 101-128, SANU, Beograd.

Vasić, V. F. \& Grubač, B. 1983. Prilozi za faunu ptica južnih delova SR Srbije (drugi deo). - Zbornik radova o fauni Srbije 2: 197-255, SANU, Beograd.

Vasić, V., Grubač, B., Sušić, G. \& Marinković, S. 1985. The Status of Birds of Prey in Yugoslavia, with Particular Reference to Macedonia. In: Newton, I., Chancellor, R.D. (eds.): Conservation Studies on Raptors, ICBP Technical Publication Series No. 5. Princeton University Press, Cambridge. pp. 45-53.

Vučanović, M. 2001. Prilog za faunu ptica planine Paštrik u Metohiji. Ciconia 10: 72-76.

Žiljak, B. 1995. U carstvu sivog sokola: vladar surih stena. Trag 14: 14-15, Novi Sad. (in Serbian)

Žuljević, A. 2000. Ornitofaunistički podaci iz okoline Niša u 1989. godini. Ciconia 9: 66-74.

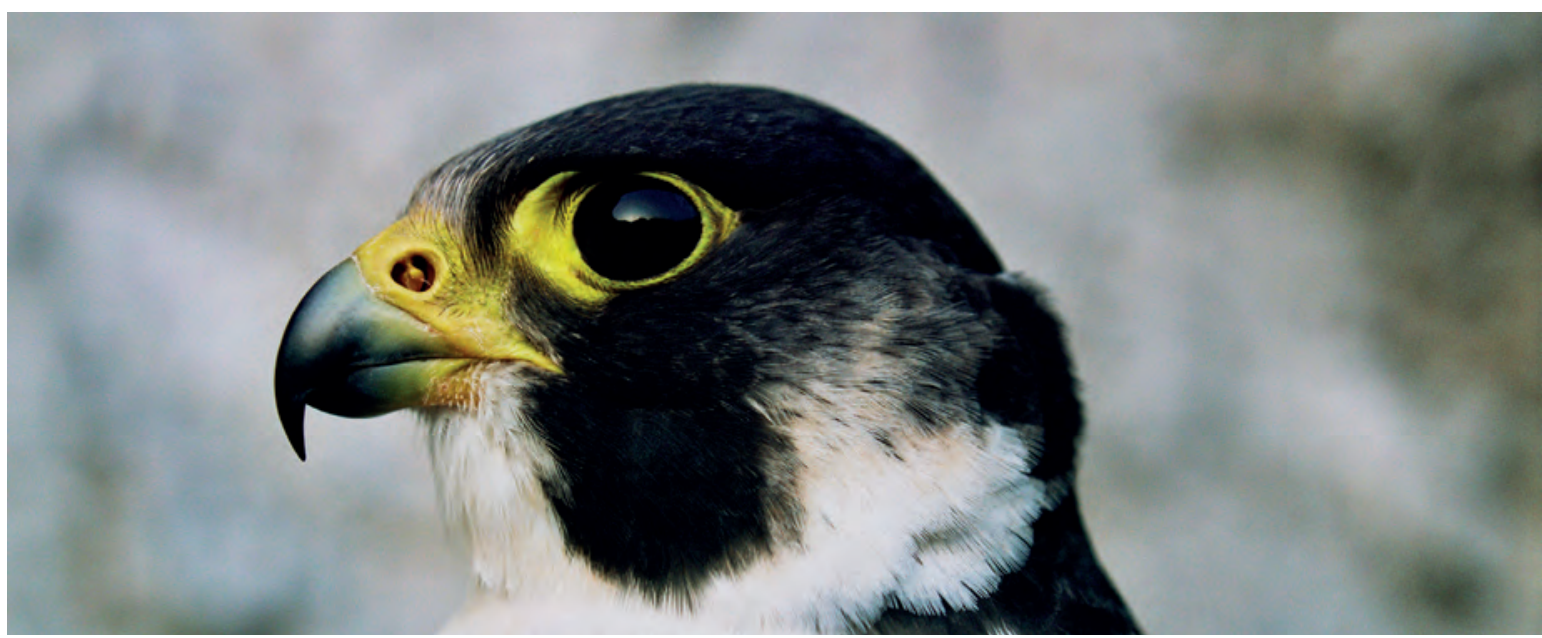




\title{
СИВИ СОКО Falco peregrinus (Tunstall, 1771) У СРБИЈИ
}

\author{
Братислав Грубач
}

У овом раду аутор даје сажети преглед публикованих и непубликованих података о дистрибуцији, популацији, тренду, екологији (станиште, исхрана и неки аспекти гнежђење) и угрожавајућим факторима сивог сокола Falco peregrinus (Tunstall, 1771) у Србији, са посебним освртом на савремени период.

Сиви соко је, углавном, широко распрострањена станарица у Србији, која се у потрази за пленом среће у веома бројним и различитим типовима станишта - ненасељеним, као и насељеним местима у низијама од 85 m н.в. до високопланинских литица, камењара, пашњака и рудина до 2500 $\mathrm{m}$ н.в. Садашња редукована гнездећа популација сивог сокола у Србији је, углавном, концентрисана у источним, знатно мање у југоисточним, западним, централним и јужним деловима земље (према подацима најновијих истраживања у периоду 2014-2018). Мањи део популације гнезди се у планинском региону Косова и Метохије (према подацима који се односе на период 1977-1997). Нема сасвим поузданих доказа гнежђења врсте у региону Војводине. У прошлости, врста је била веома ретка у Србији у периоду од краја 19. века до 1970их година. У периоду 1977-1997, као и на почетку 21. века, популација је порасла са 40-60 на 65-90 гнездећих парова. Укупна гнездећа популација сивог сокола у Србији је процењена на око 170 парова за период током друге половине 20. и почетком 21. века. Она је одређена на основу свих познатих, утврђених, вероватних и могућих места гнежђења која су дата у свим публикованим радовима, као и на основу непубликованих података. Међутим, садашња популација у Србији је упадљиво опала, и процењена је на 30-50 гнездећих парова (односи се на период 2014-2018). Тренд популације је велико опадање које се односи на период од 1998. до 2018. године, а последица је континуираног и интензивног убијања.

Сиви соко се у Србији гнезди на литицама у стеновитим брдско-планинским подручјима од око 200 до 1700 m н.в. Сматра се да је могуће ретко гнежђење и у низијским пределима, у насељеним местима, на грађевинама и на дрвећу, што није потврђено, мада постоје индиције (Marčetić,
1956; Obradović, 1997). Главна храна сивом соколу у Србији су разни голубови и грлице (углавном Columba livia $f$. domestica, и такође, C. livia, $C$. palumbus, Streptopelia turtur, S. decaocto), али и дроздови Turdus spp., чворци Sturnus vulgaris, вране и друге бројне птице.

Просечна густина укупне гнездеће популације сивог сокола у Србији процењена је на 0,19 гнездећих парова на $100 \mathrm{~km}^{2}$. Просечна густина садашње гнездеће популације сивог сокола у Сpбији процењена је на 0,03-0,05 гнездећа пара на $100 \mathrm{~km}^{2}$. Највећа густина гнежђења од 1,25 парова на $100 \mathrm{~km}^{2}$ забележена је у Србији на подручју НП „Ђердап“ (Grubač et al., 2013).

Сиви соко у Србији јаја, углавном, полаже током друге половине марта до почетка априла, а младунци полећу од краја маја до средине јуна, а у ретким случајевима током друге половине јула (вероватно поновљена или закаснела легла). Успешност гнежђења је просечно износила 2,3 или 1-4 младунаца по успешном гнежђењу $(\mathrm{N}=53)$, а продуктивност је 1,9 младунаца по пару $(\mathrm{N}=64)$ у периоду 1980- 2018. године.

Масовно илегално убијање сивог сокола и других птица грабљивица од стране одгајивача голубова, а у мањем обиму и од ловаца, главни су угрожавајући фактори и велики проблем заштите ове угрожене врсте у Србији. Према разним извештајима и анкетама у Србији је убијено најмање 163-166 сивих соколова од стране одгајивача голубова, и то у периоду 1960-2018. године. Такође, голубари су убили још 10-11 младунаца у гнезду, а ловци 22 јединке у периоду 1978-2018. Укупан број убијених сивих соколова је, вероватно, знатно већи, с обзиром на то да велики број убијених птица није забележен. Убијање птица од стране одгајивача голубова је највећи узрок смртности сивог сокола у Србији, и оно представља око 94\% узрока морталитета врсте, а велики проблем представља и употреба отрова и трокраких удица за убијање сивог сокола и других птица грабљивица. Коришћење отрова се изводи премазивањем перја отровима или другим токсичним материјама на живим птицама (креозаном, карбофураном и другим опасним материјама). 
Пљачка гнезда (узимање јаја и младунаца) сивог сокола од стране страних и домаћих крадљиваца за потребе соколарства, за музејске збирке, колекције и у друге сврхе, релативно је честа појава још од 1970-их година. Обим данашње илегалне пљачке гнезда и трговина сивим соколовима у Србији су непознати, мада је извесно да су ове појаве присутне. Иако у мањем обиму, евидентирано је и страдање сивог сокола услед колизије са разним жицама и објектима. У прилог томе су и забележених пет случајева налетања ове врсте на жице и објекте (Marčetić \& Andrejević, 1960). Мeђу угрожавајућим факторима су и губитак и деградација станишта и узнемиравање сивог сокола на местима гнежђења у Србији, мада нема података о размерама и последицама дејства ових фактора.
Имајући у виду велику угроженост сивог сокола у Србији, неопходно је да се предузму специјалне ургентне мере и активности заштите врсте (Grubač et al., 2018). Оне подразумевају спречавање и сузбијање тровања и других метода убијања птица од стране одгајивача голубова и ловаца, пљачке гнезда и узнемиравања птица на гнездима. Такође, неопходно је детаљно и организовано истраживање и праћење стања популације и тренда врсте, као и сузбијање угрожавајућих фактора. Уколико се утврди даљи пад бројности популације неопходно је да се формира центар за вештачко размножавање у заточеништву коришћењем пронађених и збринутих рањених и повређених јединки које нису способне за самосталан живот у дивљини.

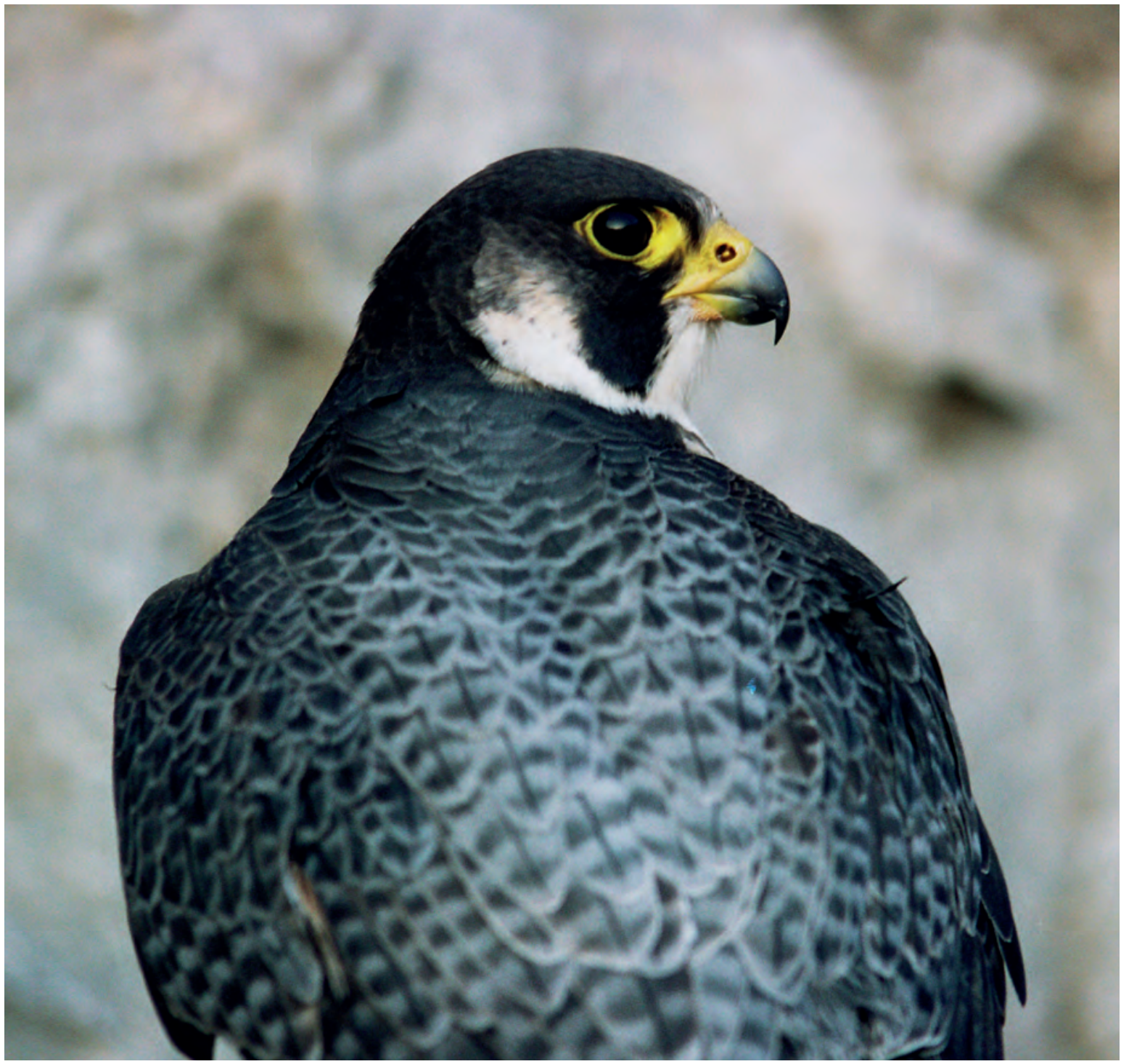

Fig. 5: Adult male of the peregrine falcon. Western Serbia, December 2003. Photo: B. Grubac 